\title{
7.1 \\ Apertura: \\ La Financiación de la Empresa Cooperativa
}

\author{
Dr. Alfredo Ispizua
}

Director de Economía Social del Gobierno Vasco

Nola ihardunaldi hau euskal erakunde unibertsitario batek antolatu duen, dagokiona euskaraz mintzatzea da, hein batean, behintzat.

Hau honela, eta harira joan da, gogoeta labur batzuk egin nahi nituzke zuengana helarazi.

Gaur egun, eta are gehiago, etorkizunean, merkatu aldakor eta globalaren erronkak direla medio, ezinbestekoa zaie kooperatibei egokitzea - gutxienez, abiadura berean baztertuta ez badute geratu nahi.

Eta egokitze honetan finantz baliabideak esangura garrantzitsua dute oso.

Betidanik, kapital ekarpenak urriak izan dira kooperatibetan normalki, lanaren menpe bait daude printzipioz; baina, gero eta gehiago, enpresaren ikuspegitik, behar hori haunditzen doa eta, era berean, eragin garrantzitsua sortarazten sozietate aldetik.

Halaber, ebazpen eraginkorrak aurkitzerakoan, kooperatiben nortasun berezia kontutan izan beharko da.

Beraz, gakoa honetan datza: nola asetu egungo «domu gose» kooperatibak, (capital hungry co-operatives), indarrean dauden tresna juridikoak erabiliz, edota, alderantziz, nola osatu arau berriekin errealitate berriaren eskakizun ekonomikoak, kooperatibaren eite juridikoa galdu gabe.

Horretarako, ikuspuntu aproposena guretzat europearra dirudi.

Alde batetik, kooperatiba legeria konparatuak erakus diezaiguke norainoko aurrerapenak dituzten beste ordenamendu juridikoetan, zer eratako irtenbideak aurkitu diren teknikoki. 
Bestalde, ohartaraztekoa da funtsezko printzipioak internazionalki onartuak direla eta, normalki, estatuetako kooperatiba arauak jarraitzen dituztela, urre edo urrutiagotik, kasuan kasuko.

Beraz, badira, hemen azaltzen den gaiari lotuta, europear legeriek arautu dituzten baliabide bereziak. Beraiek miatuz, informazio edota akademi ikuspegitik aparte, emaitza praktikoak atera ditzakegu.

Horretaz aparte, Europako Komunitate mailan, eta erakunde arteko harremanetan, Gizarte Ekonomiarako enpresei buruzko azken agirietan, finantz kezka argi azaltzen dira, irtenbideak aztergai ezartzen direlarik.

Haietan ezagutarazten da nola nazio arteko lehiaketak beharturik, enpresa hauek, Gizarte Ekonomiarakoak alegia, berezitasun hori dela medio, diru ugaritasun premian aurkitzen direla: diru kopuru, baita diru mota problematika latzak dituztelarik. Kideen finantz laguntza nahikoa ez denez, kanpora jo behar dute, kanpotarren domu ezarpenera.

Hala ere, bide hau jarraitzeak ez du esan nahi, edo behintzat, ez luke esan nahi beharko, kapitalarekiko pertsonaren goi posizioa aldatzeko zorian utziko lukeenik.

Horregatik, Europear Ekonomia eta Gizarte Komiteak gomenda ohi da Gizarte Ekonomiako enpresen finantz sistemak aipatutako alde biak kontutan izatea: sozietatearen nortasun pertsonala zaindu eta kanpotar domudunak erakarri. Adibide bezala, espreski, aitatzen ditut «títulos de participación». "fondos de garantía» eta "fondos de participación», besteak beste.

Gainera, beste egitasmo batzuk kaleratu dira, non «titulaires de parts ne diposant de droit de vote» eta "obligations» eta "autres valeurs mobilièrs» erregulatzen diren, adibidez.

Saio hauek kontuan izan behar ditugu, kooperatibekiko Europako erakundeen norabide politiko-juridikoa erakus diezaigukelako, baita guregan eragin zuzena eduki lezakelako ere.

Esan den guztia kontutan harturik, kooperatiben finantz posibilitateak ezartzea lehen eta behin, litzateke ezinbestekoa. Adituaren lanak ere har ditugu, Alan Thomas, Ean Louis LAVILLE, Jean Francois MARCHANT, Fracoise SOULAGE, J.P. FELDBUSH, eta abar luze bat gaur egundaino.

Hauek, proposamen berriekin hornitzen dute ekarpen «tradizionala», hau da: kidearen erakarpenak, emendio baltzak eta prestatutako domua (Münkner). 
En efecto, la preocupación por la financiación suficiente, tanto en el nacimiento como en la consolidación de la empresa cooperativa, ha sido, es y será una preocupación constante en el mundo cooperativo.

Fue una preocupación del legislador vasco de 1982; lo fue del de 1993 y lo ha sido del de 2000.

Así, han surgido en el ámbito jurídico, una serie de instrumentos financieros de índole variada: como los títulos participativos o las participaciones especiales que procuran cubrir carencias tradicionales de financiación.

Además, en la práctica vasca de los últimos años se han establecido también nuevas instituciones que facilitan la financiación cooperativa como es el caso de OINARRI, Sociedad de Garantía Recíproca, con finalidad avalista.

Por otra parte, en la práctica internacional, diversas alternativas financieras han nacido extra muros de la banca comercial tradicional, como son las cajas solidarias, bancas alternativas, banca ética, etc.

Con todo, aquí y ahora, el papel de la financiación bancaria resulta nuclear en la financiación de cualquier inversión productiva inicial o en fase expansiva de las empresas cooperativas, por las características propias de este tipo de entidades e independientemente de los aspectos cíclicos generales; esto es, que para el 2003 se prevea una mejora del ahorro empresarial y por lo tanto, disminuya la necesidad de financiación, no invalida el aserto principal de su debilidad financiera.

Como tampoco lo invalidan los datos que resultan de las últimas cuentas de la Economía Social correspondientes al bienio 1999-2000.

Por eso, analizar sistemas, métodos de financiación cooperativa, tanto nuevos como la mejora y adaptación de los existentes, es un reto y una oportunidad para la comunidad universitaria en general, y para la Asociación Internacional de Derecho Cooperativo en particular, dada su posibilidad de análisis comparativo de culturas económicas y jurídicas cooperativas muy diversas de la nuestra.

Y este Seminario que Vds. tienen la oportunidad de celebrar puede servir, efectivamente, en la investigación de las posibilidades de financiación cooperativa; una materia de actualidad permanente en el mundo cooperativo.

Eskerrik asko. 